\title{
Seroprevalence of hepatitis B virus of university students in Kogi State, Nigeria
}

\author{
Agbana Busayo Emmanuel ${ }^{*}$, Akogu Simon P.O², Alabi Oladele Joshua ${ }^{3}$, Akwu B. Peter ${ }^{4}$ \\ ${ }^{1-4}$ Lecturer, ${ }^{1,3}$ Dept. of Community Medicine, ${ }^{2}$ Dept. of Obstetrics and Gynaecology, ${ }^{4}$ Dept. of Anatomy, ${ }^{\mathbf{1 - 4}}$ Kogi State University Teaching \\ Hospital, Kogi State University, Anyigba, Nigeria. \\ *Corresponding Author: Agbana Busayo Emmanuel \\ Email: agbanabusayo@yahoo.com
}

\begin{abstract}
Introduction: About half a million people die globally from chronic Hepatitis B Virus (HBV) infection.

Objectives: This study was conducted to determine the distribution and risk factors of the infection among university students in Kogi state.

Materials and Methods: Data on demographic and risk factors indicators were collected using questionnaires and blood samples tested for HBV.

Results: $(47.4 \%)$ of the respondents were engaged in the sharing of sharp objects, only (5.7\%) were engaged in IDU. One-tenth, (20.0\%) of the respondents were engaged in unprotected sexual intercourse (Only 20.8\% of age group less than or equal to 20 had good knowledge of prevention of HBV. Less than one- tenth, $(3.1 \%)$ were positive to Hepatitis B Surface Antigen (HBSAg) of respondents within the age group 21-25 compared with about one-quarter, (15.2\%) of those in the age group 26-30 that were positive to HBsAg.
\end{abstract}

Conclusion: This study highlights the need for improved awareness among University students in Kogi State.

Keywords: Kogi state university students, Hepatitis B virus, Seroprevalence.

\section{Introduction}

Viral hepatitis is a medical condition defined by the inflammation of the liver and characterized by the infiltration of inflammatory cells in the tissue of the organ. ${ }^{1}$ It may occur with limited or no symptoms, but often leads to jaundice, poor appetite and malaise. Hepatitis is acute when it lasts less than six months and chronic when it persists longer. The condition can be self-limiting (healing on its own) or can progress to fibrosis (scarring) and cirrhosis. It is important to state that viral hepatitis is the most common cause of liver inflammation which leads to weight loss, bleeding, peripheral edema and accumulation of ascities (fluid in the abdomen) and other associated complications, for example, hepatorenal syndrome. ${ }^{1}$

Hepatitis B virus (HBV) is a silent killer disease with many carriers not realizing that they are infected with the virus. Important factors contributing to HBV spread include unsafe sex, use of therapeutic injection, blood transfusion and mother-to-child transmission. Among the other high risk adults population are the people with multiple heterosexual partners, men who have sex with men, health workers and intravenous drug users. However, students are known to fall within this high risk group. ${ }^{2,3}$

HBV cause acute and chronic hepatitis with a tendency to progress to liver cirrhosis and hepatocellular carcinoma. ${ }^{2,3}$ There are broadly three strategies for the control of HBV infection and these includes Health education and immunization for at risk population after a negative result to screening, use of antiviral drugs and immunostimulatory therapy with interferon for infected people. ${ }^{4,5}$

Worldwide, about two billion people are estimated to have been infected with hepatitis B virus infection with over 300 million of those infected have chronic infections. Approximately 7,80,000 persons die each year from hepatitis B virus infection, 650,000 from cirrhosis and liver cancer due to chronic hepatitis B infection and another 130,000 from acute hepatitis B. ${ }^{6}$ It has been estimated that, annually more than half a million people die globally from chronic HBV infection, cirrhosis and liver cancer. ${ }^{1}$

In Nigeria about 20 million people are infected, this figure makes Nigeria to be classified among the group of countries endemic for HBV infection with prevalence rates ranging from $2.2 \%-65.9 \%{ }^{8}$

In Nigeria, knowledge of HBV is still at the poor level. Few studies that have been carried out among young persons in Nigeria all revealed poor awareness and knowledge of HBV. A study carried out in Crawford University in Ogun State Nigeria found out that most people respondents had no knowledge of the virus and those who had a little knowledge had not been vaccinated or are not sure if they had been vaccinated. Only about 3.0\% knew that they had been vaccinated while the others did not even know about the virus or its vaccination. ${ }^{9}$

When risk of infection was identified and analyzed after conducting a study among students studying in a tertiary institution, students with history of sexually transmitted infections (11.9\%) and those who had more than five sexual partners $(8.3 \%)$ were significantly associated with the infection.

However, in Kogi state there have been no reports on the risk factors and prevalence of hepatitis among University students in the state. This study was then designed to assess the prevalence of hepatitis B Virus infection and to identify the risk factors for HBV among university students in Kogi State, a North central part of Nigeria. This study would serve as an important source to identify the prevalence of HBV among university students in Kogi state, which will provide baseline data for future 
assessment of the impact of $\mathrm{HBV}$ and risk factors among University students in Kogi state.

\section{Materials and Methods}

Description of study area

Kogi State was created August 27th 1991 as part of North central States of Nigeria with her headquarter at Lokoja. It has two distinct weather;rain and dry season with an annual rainfall of $1016 \mathrm{~mm}$ to $1524 \mathrm{~mm}$. It lies on latitude $7.49^{\circ} \mathrm{N}$ and Longitude $6.45^{\circ}$ E.The State has three universities, namely, Federal University Lokoja, Kogi State University Anyigba and Salem University Lokoja.

\section{Study design}

This was a descriptive cross-sectional study conducted on undergraduate students of Universities in Kogi State. A standard structured self-administered questionnaire was used to assess the knowledge and Risk factors among the student regarding $\mathrm{HBV}$ infection, and screening were also done for the detection of Hepatitis B Surface Antigen (HBSAg).

\section{Study population}

This includes undergraduate students of the three Universities in Kogi State, who are 18 years and above, give their consent and a full time undergraduate Student.

\section{Ethical consideration}

Ethical clearance was obtained from the ethical review committee of the Kogi State University Teaching Hospital, Anyigba. Informed consent was obtained from the students before subject enrolment after a clear explanation to them. Permission was sought from the directors of all the medical centers of the institutions, positive cases were referred to the Gastroenterology Clinic of Federal Medical Centre Lokoja for further evaluation, treatment, management and follow up. Health talk was organized for the participants after retrieving back the questionnaire, in order to update their knowledge regarding $\mathrm{HBV}$ infection.

\section{Sample size determination}

A minimum sample size was calculated based on a prevalence of $11.5 \%$ from previous studies among University student in Nigeria. ${ }^{7}$

Minimum Sample size for the study will be estimated using Fisher's Formula.

$$
n=\frac{Z^{2} x p q}{d^{2}}
$$

$\mathrm{n}=$ minimum sample size

$\mathrm{Z}=$ normal standard deviate for the required level of confidence taken as 1.96

P- Estimated prevalence of the Condition.

$\mathrm{q}=1.0-\mathrm{p}$

$\mathrm{D}=$ Tolerable margin of error usually set at $5 \%$

$$
Z=\frac{1.96^{2} \times 0.115 \times 0.885}{0.05 \times 0.05}=156
$$

Allowing for Attrition of $10 \%,(16)=172$. A total number of 500 students were recruitted, to improve the validity, power,reliability and generalizability of the study.

\section{Sampling techniques}

Multi- stage sampling techniques was used for the selection of the study participant/sample of the 20,000 estimated population of Kogi State University Anyigba, 357 were proportionally selected, of the 6,000 estimated population of Federal University Lokoja,107 were proportionally selected and of the 2,000 estimated population of Salem University Lokoja, 36 were selected proportionally.

\section{Research instruments}

This will involve the use of structured self-administered questionnaire and Serological test for HBSAG.

\section{Pre-test}

Fifty questionnaires, which is $10 \%$ of 500 (desired sample size) was pretested among students Benue State University Makurdi. After which appropriate corrections was made to the questionnaires. The pretested questionnaire was used to identify problems with validity of the test instrument and interpretation and analysis of data obtained from it.

\section{Serological test for HbsAg}

HBsAg screening was done on all serum samples using the Acon HBsAg One Step Diagnostic Test Strip by Acon Laboratories, Inc. It is a rapid chromatographic immunoassay for the qualitative detection of $\mathrm{HbsAg}$ with specificity of $100 \%$. The Kit is stable and potent for one year at temperature $37^{\circ} \mathrm{C}$ or room temperature. ${ }^{10}$ The same 500 respondents who were selected (multistage sampling techniques) for the questionnaire were the participants who were screened for the HBsAg following the manufacturer's protocol for the kit. The questionnaires were coded with the correspondents' blood samples (bottles).

\section{Data analysis}

The findings and laboratory results was recorded in the study proforma. After appropriate verification, data were entered into a meter sheet and analysis was carried out using the Epi-info database and statistics software for Public Health profesionals version 3.4.1. Data obtained from the study proforma were entered using numeric codes. Frequency distribution tables of variables were generated, measure of central tendency and dispersion of quantitative variables as well as proportion of qualitative variables were determined. Students/Subjects were grouped according to Age- group and Sex, chi-square test for significance of the difference between categorical variables. A P-value of < 0.05 will be considered significant. 


\section{Results}

A total of five hundred (500) questionnaires were administered across the selected universities and all were correctly completed and analyzed. Response rate was $100 \%$.

Table 1: Socio-demographic characteristics of respondents

\begin{tabular}{|l|c|c|}
\hline Variables & Frequency & Percentage \\
\hline Age groups & & \\
\hline$\leq 20$ & 168 & 33.6 \\
\hline $21-25$ & 291 & 58.2 \\
\hline $26-30$ & 33 & 6.6 \\
\hline$\geq 31$ & 8 & 1.6 \\
\hline Mean \pm SD (Range) & $21.78 \pm 3.02$ & $15-43$ \\
\hline Level of Education & & \\
\hline 100 & 115 & 23.0 \\
\hline 200 & 136 & 27.2 \\
\hline 300 & 70 & 14.0 \\
\hline 500 & 123 & 24.6 \\
\hline 500 & 56 & 11.2 \\
\hline Institution & & 71.4 \\
\hline KSU & 357 & 21.4 \\
\hline FUL & 107 & 7.2 \\
\hline SALEM & 36 & 98.2 \\
\hline Marital Status & & 1.4 \\
\hline Single & 491 & 0.4 \\
\hline Married & 7 & \\
\hline Widowed & 2 & \\
\hline
\end{tabular}

From (Table1) the mean age of respondents was $21.78 \pm 3.02$ years, $55 \%$ of the respondents were female while $45 \%$ of the respondents were male. Majority of the students were from Kogi State University while $21.4 \%$ were students from Federal University Lokoja, only $7.2 \%$ respondents were students of Salem University.

Table 2: Knowledge of respondents on mode of transmission of hepatitis B

\begin{tabular}{|l|c|c|c|}
\hline Transmission methods & Yes (\%) & No (\%) & Don't Know (\%) \\
\hline It can be transmitted through food or drink & $59(21.0)$ & $114(40.6)$ & $106(38.4)$ \\
\hline Through blood & $191(68.0)$ & $11(3.9)$ & $79(28.1)$ \\
\hline Through sex & $157(55.9)$ & $32(11.4)$ & $92(32.7)$ \\
\hline Through sharing of needles & $143(50.9)$ & $43(15.3)$ & $95(33.8)$ \\
\hline Through mother to infants & $130(48.4)$ & $30(10.7)$ & $115(40.9)$ \\
\hline Through hand shaking & $57(20.3)$ & $157(55.9)$ & $67(23.8)$ \\
\hline
\end{tabular}

About $28.1 \%$ of the respondents does not know that HBV infection can be transmitted through blood, similarly $32.7 \%$ does not know that HBV can be transmitted through sexual intercourse and $21 \%$ of the students believed that the infection can be transmitted through food and drink (Table 2).

Table 3: Knowledge of respondents on prevention of hepatitis B

\begin{tabular}{|l|c|c|c|}
\hline Preventive ways & Yes (\%) & No (\%) & Don't Know (\%) \\
\hline It can be prevented by Hb Vaccince & $242(86.1)$ & $8(2.8)$ & $31(11.0)$ \\
\hline Regular exercise & $189(67.3)$ & $17(6.0)$ & $75(26.7)$ \\
\hline By taking balanced diet & $32(11.4)$ & $108(38.4)$ & $141(50.2$ \\
\hline By good hand hygiene & $57(20.3)$ & $98(34.9)$ & $126(44.8)$ \\
\hline By the use of condom & $128(45.4)$ & $53(18.9)$ & $100(35.7)$ \\
\hline
\end{tabular}

Majority of the respondents $(86.1 \%)$ know that HBV infection can be prevented by vaccination, $67.3 \%$ believes exercise can prevent the infection, while $35.7 \%$ don't know that use of condom can prevent HBV infection (Table 3). 
Table 4: Association between socio-demographic characteristics and prevalence of infection of HBV

\begin{tabular}{|c|c|c|c|c|}
\hline Variables & \multicolumn{2}{|c|}{ HBV Status } & & \\
\hline & Positive (\%) & Negative (\%) & $\chi^{\mathbf{2}}$ & P \\
\hline Age groups & & & 11.074 & 0.011 \\
\hline$\leq 20$ & $7(4.2)$ & $161(95.8)$ & & \\
\hline $21-25$ & $9(3.1)$ & $282(96.9)$ & & \\
\hline $26-30$ & $5(15.2)$ & $28(84.8)$ & & \\
\hline$\geq 31$ & $0(0.0)$ & $8(100.0)$ & & 0.840 \\
\hline Gender & & & 0.041 & \\
\hline Male & $9(4.0)$ & $216(96.0)$ & & \\
\hline Female & $12(4.4)$ & $263(95.6)$ & & \\
\hline Institution & & & 18.597 & \\
\hline KSU & $15(4.2)$ & $342(95.8)$ & & \\
\hline FUL & $0(0.0)$ & $107(100.0)$ & & \\
\hline SALEM & $6(16.7)$ & $30(83.3)$ & & \\
\hline Marital Status & & & 0.402 & \\
\hline Single & $21(4.3)$ & $470(95.7)$ & & \\
\hline Married & $0(0.0)$ & $7(100.0)$ & & \\
\hline Widowed & $0(0.0)$ & $2(100.0)$ & & \\
\hline
\end{tabular}

From Table 4, University and age of the respondents were found to be statistically significantly associated with the prevalence of HB status among the respondents. Less than one- tenth, $(3.1 \%)$ were positive to HBsAg of respondents within the age group 21-25 compared with about one-quarter, (15.2\%) of those in the age group 26-30 that were positive to $\mathrm{HBsAg}$. This observed difference was statistically significant, $\mathrm{p}<0.05$. Regarding the marital status, none of the married respondents were positive to HBsAg and $4.3 \%$ of the singles were positive to HBsAg. The difference reported was not statistically significant at $\mathrm{P}>0.05$.

Table 5: Relationship between socio-demographic variables and knowledge of prevention

\begin{tabular}{|l|c|c|c|c|}
\hline Variables & \multicolumn{2}{|c|}{ Knowledge of prevention } & & \\
\hline & Poor (\%) & Good (\%) & $\chi^{2}$ & P \\
\hline Age groups & & & 2.815 & 0.421 \\
\hline$\leq 20$ & $133(79.2)$ & $35(20.8)$ & & \\
\hline $21-25$ & $232(79.7)$ & $59(20.3)$ & & \\
\hline $26-30$ & $30(90.9)$ & $3(9.1)$ & & \\
\hline$\geq 31$ & $7(87.5)$ & $1(12.5)$ & & \\
\hline Gender & & & 0.862 & 0.353 \\
\hline Male & $185(82.2)$ & $40(17.8)$ & & \\
\hline Female & $217(78.9)$ & $58(21.1)$ & & \\
\hline Institution & & & 9.901 & 0.007 \\
\hline KSU & $284(79.6)$ & $73(20.4)$ & & \\
\hline FUL & $82(76.6)$ & $25(23.4)$ & & \\
\hline SALEM & $36(100.0)$ & $0(0.0)$ & & \\
\hline Marital Status & & & 0.621 & 0.733 \\
\hline Single & $394(80.2)$ & $97(19.8)$ & & \\
\hline Married & $6(85.7)$ & $1(14.3)$ & & \\
\hline Widowed & $2(100.0)$ & $0(0.0)$ & & \\
\hline
\end{tabular}

Only $20.8 \%$ of age group less than or equal to 20 had good knowledge of prevention of HBV, as compared with age group greater than or equal to 31 age group. There was statistically significant association between level of education among respondents and knowledge of prevention of $\mathrm{HBV}$, as $\mathrm{p}<0.05$. Significant relationship also exists between institution of respondents and knowledge of prevention (Table 5).

\section{Discussion}

This study revealed that more than half of the students were aware of the disease but an unsatisfactory knowledge level on HBV infection in general whereby highest proportion, constituted those with poor knowledge score and just 20.2\% had good knowledge score. This significant knowledge gap of University students on HBV infection regarding its cause and risk factors pose a serious danger in the control of the disease. This study has provided information on the burden of HBV infection among the students of Universities in Kogi State.

The mean age of students in this study was $21.78 \pm 3.02$ years. This is similar to the study conducted among University students in Bangui, central Africa Republic where the mean age was $220.8 \pm 4.1{ }^{11}$ and the study carried 
in Port Harcourt Nigeria where the age was $22.4 \pm 2.4 .^{12}$ Majority of respondents were female (55\%). Ojo et al ${ }^{13}$ also reported a similar finding among freshmen in Ile-Ife Nigeria.

More than half of the students know about HBV infection, however only $20.2 \%$ had good knowledge of HBV infection. The poor knowledge of HBV infection is consistent with the findings from a similar study conducted among undergraduate students of Crawford University in Osun State, where majority of the students had poor knowledge. This may be due to similarities of the respondents in the two studies. On the contrary, a study by Omuemu et al., 65\% had good knowledge. ${ }^{10}$ The higher proportion respondents with good knowledge of $\mathrm{HBV}$ recorded in these studies compared with the findings of this present study may have resulted from the differences in the study participants. The study was conducted among medical students who by the nature of their curriculum could have learnt about HBV infections in the course of their training. The public health implication of their poor knowledge score in this study is that many of the university students lack the basic knowledge of HBV infection and therefore the control of the disease within the University community may pose a serious challenge.

The overall prevalence of HBV infection among the study was $4.2 \%$. This is low compared with the prevalence of $11.5 \%$ found in a similar study in North Central Nigeria among tertiary students but similar to $5.2 \%$ prevalence found among undergraduate students in Crawford University in Osun State. ${ }^{14}$

There were also variations in the prevalence of HBV infection across the Universities which is below the national HBV carriage rate (9-39\%). ${ }^{15,16}$ The highest prevalence rate of $3.0 \%$ was recorded among KSU students while the least of $0 \%$ was recorded among FUL students. These variations could be due to the varied degree of exposure of individual respondents to risk factors for HBV infections which may not be uniformly distributed among the respondents in the various institutions. Factors such as illicit intravenous drug use, blood transfusion and unprotected sexual intercourse have been documented as risk factors for HBV infection. ${ }^{17}$ These as well as sharing of sharp objects and history of hospitalization were common among respondents of in this study.

Findings show that $13.4 \%$ of respondents had multiple sexual partners, $27 \%$ of respondents were involved in sharing sharp objects while $12.8 \%$ of participants were involved in indiscriminate intravenous drug use. Involvement in such behavior by the respondents shows clearly that the respondents have poor knowledge of the disease among the students, with likelihood of rapid transmission. This requires urgent need for health interventions to prevent various misconceptions held by the students about HBV infection and the various practices that might contribute to the spread.

A significantly higher proportion of students less than 20 years of age had poor knowledge of the transmission of HBV infection and this finding is consistent across all the socio demographic variables. Similarly knowledge of preventive measures against HBV infection was found to be persistently low across the socio demographic variables in the study.

With the poor knowledge of risk factors for HBV infection reported in this study, there is a tendency for continuous exposure and transmission of the disease among the students. This will contribute to the global burden of the disease in terms of long term complications of HBV infection such as liver cancer and cirrhosis

\section{Conclusion}

The reported prevalence in this current study was $4.2 \%$ and the range across the Universities was $0 \%$ and $4.2 \%$. Illicit intravenous drug use, blood transfusion and unprotected sexual intercourse have been documented as risk factors for HBV infection as well as sharing of sharp objects and history of hospitalization were common among respondents in this study as the risky behavior in the spread of HBV infection. Therefore there is a need to educate the students about the dangers associated with these risky behaviors in order to control the spread of the deadly disease within the school environment and beyond

\section{Recommendation}

The school authority needs to organize regularly public lectures, seminars, distribution of IEC materials in strategic places in the universities and also make vital health information available in school websites and notice boards his will correct various misconceptions by students towards the HBV infection. There is need to conduct routine screening of hepatitis B virus among students in the higher institutions of learning in Nigeria especially newly admitted students. Students that are tested negative can be vaccinated according to the national guidelines. The students should be informed against risky behaviors such as unprotected sexual intercourse illicit drugs use, sharing of sharps objects and acupuncture and tattooing among themselves.

\section{Acknowledgements}

Special thanks to the Tertiary Education Trust Fund (TETFUND) RESEARCH GRANT 2018, which was used for this study.

\section{Source of funding}

Tertiary Education Trust Fund (TETFUND) Research Grant 2018.

\section{Conflict of interest: None.}

\section{References}

1. Blumberg BS, Gerstley BS, Hungerford DA, London WT, Suntnik AJ. A serum Antigen, Leakaemia and Hepatitis. Ann Int Med.66:924-31.

2. Okochi K, Murakami S. Observations on Australia Antigen in Japanese. Vox Sang. 1968;15:375-85.

3. Jonas MM. The liver and Bile ducts In, Rudoph CD, Rudoph AM, Hostler M K. Rudoph paediatrics. New York: McGraw Hill companies $21^{\text {st }}$ ed. 2003;1479-157. 
4. Fawad K, Sulaiman S, Ihteshamud DQ. Hepatitis B virus infection among different sex and age groups in Pakistani Punjab. Virol J. 2011;8:225.

5. Colin W, Shepard P, Edgar P, Simard. Hepatitis B virus Infection: Epidemiology and Vaccination. National center for infectious diseases, CDC and prevention. Atlanta, GA. Epidermiol Rev. 2006;28:112-25.

6. Hutin Y, Harpaz R, Drobeniue J, Melnic A, Ray C. Injections given in health settings as a major source of acute hepatitis in maldova. Int J Epidermiol. 1999;28:782-6.

7. Pennap GR, Nwachukwu O, Ishaleku D, Ombugadu RJ. Hepatitis B virus carriage among students of a Nigerian Tertiary Institution;A cohort of Eligible blood donors. Res $J$ Med Sci. 2011;(2):90-3.

8. World Health Organization, Hepatitis B http:Lllwwwwho.inflinf-fslenlfact204.html.Assessed on the $23^{\text {rd }}$ of March 2012.

9. Babalola E T. Ainabe O B and Okonko I O. Confirmation of Hepatitis B Surface Antigen (HBsAg) Among Selected Tertiary Institution Students in Ogun State, Nigeria. Nat Sci. 2013;11(3):107-13]. (ISSN: 1545-0740).

10. Margaret SM. KAP regarding prevention of HBV infection in final year students Nurses in Gauteng Province, South Africa. MPH 2010.

11. Narcissep K, Souleyman B, Alexandre M, Josime L, Aubin B, Alain LF. Prevalence of HBV markers in a cohort of student in Bangui, Central republic. BMC Infect Dis. 2010;10(2):226
12. Jeremiah ZA, Tony EEO. Seroprevalence of transfusion transferable infection among university fresh students in Port Harcourt in Nigeria. J Hepat. 2009;9:276-61.

13. Ojo OS, Akonai AK, Thurz M, Ndubaba DA, Durosimi MA, Adeolu OO et al. Hepatitis D virus antigen in HBsAg positive chronic liver disease in Nigeria. East Afr Med J 1998;75:32931.

14. Obekpa S, Khatib M, Mbwas M, Francis A, Das N. Prevalence of HBV and HIV Among Students and Staff of University of Jos, Nigeria. Int J Res Pub. 2014;4(1):2250-3.

15. Cindy M, Weinbaum MD. Division of Viral Hepatitis, National Centre for HIV/AIDS, Viral Hepatitis, STDs, and TB prevention. 2008;57:1-20.

16. Bwogi J, Braka F, Makumbi I, Mishra V, Bakamutumaho B, Nanyunja M., et al Hepatitis B infection is highly endemic in Uganda:findings from a national serosurvey. Afr Health Sci. 2009;9 2):98-108.

17. Emechebe GO, Emodi IJ, Ikefuna AN, Ilechukwu GC, Igwe WC, Ejiofor OS et al. Hepatitis B virus infection in Nigeria - A review. Niger Med J. 2009;50:18-22.

How to cite this article: Agbana BE, Akogu SPO, Alabi OJ, Akwu BP, Seroprevalence of Hepatits B Virus of University Students in Kogi State, Nigeria. Indian $J$ Forensic Community Med 2019;6(4):202-7 